Vol. 13 (2004): 124-137.

\title{
Relating microstructure, sensory and instrumental texture of processed oat
}

\author{
Marjatta Salmenkallio-Marttila, Raija-Liisa Heiniö, Olavi Myllymäki, Martina Lille, Karin Autio \\ and Kaisa Poutanen \\ VTT Biotechnology, PO Box 1500,02044 VTT, Finland, e-mail: marjatta.salmenkallio-marttila@vtt.fi
}

\begin{abstract}
This study is a part of a larger project aiming to produce new, healthy, and tasty food ingredients from oat. Germination and different heating processes can be used to improve the texture and flavour of cereals. In this study effects of germination and wet and dry heating on the microstructure, instrumental structure and sensory properties of two oat varieties were assessed. The microstructure of native, germinated, autoclaved and extruded grains of the hulled cv. Veli and hull-less cv. Lisbeth was examined by light microscopy, the texture was measured by determining the milling energy and hardness of the grains and sensory characteristics were evaluated with descriptive sensory profile analysis. In cv. Veli the cells of the starchy endosperm were smaller than in cv. Lisbeth and $\beta$-glucan was concentrated in the subaleurone layer. In cv. Lisbeth $\beta$-glucan was evenly distributed in the starchy endosperm. The grains of $\mathrm{cv}$. Lisbeth were more extensively modified in the germination process than the grains of $\mathrm{cv}$. Veli, otherwise the effects of processing on the grains of the two cultivars were similar. Germination caused cell wall degradation, autoclaving and extrusion cooking caused starch gelatinization. Autoclaving resulted in the hardest perceived texture in oat. Gelatinization of starch appeared to contribute more to the hardness of oat groats than the cell wall structure. Of the instrumental methods used in this study the milling energy measurement appeared to be the most useful method for the analysis of the effects of processing on grain structure.
\end{abstract}

Key words: oats, processing, microstructure, texture, sensory evaluation

\section{Introduction}

Snacks are an increasing sector in the food market. Convenience and health aspects favour development of new whole grain based ingredients and snack foods. Oat products have captured the attention of food industry because the soluble $\beta$-glucans abundant in oat bran have been shown to have cholesterol-lowering effects in clinical studies. The nutritional value of the dietary fibre components of other cereals as well is receiving great attention. Technologies for germination and processing of oats have been devel- 
Vol. 13 (2004): 124-137.

oped to produce new oat snacks (Heiniö et al. 2001, 2002, Wilhelmson et al. 2001). Processing oats for new products is a rewarding challenge, by using oat we can create products with more variety and improved nutritional quality. Oat is also well suited for organic production and has been shown to be suitable for celiac patients.

In addition to flavour the sensory texture of a product is one of the main characteristics determining its success (Lillford 2000). Structural characteristics of cells and tissues are important in studying physiological and structural interactions within cereal grains that influence grain quality and performance in industrial processes. Especially the structure and composition of cell walls are the basis of many process applications of cereal grains (Poutanen 2000). Food processes, including milling, malting, extrusion cooking, and baking, produce microstructural changes in proteins, cell wall components and starch. These changes can have a large effect on the quality of the end product. The microstructure determines the appearance, texture, taste perception and stability of the final product. A variety of microscopic techniques is available for studying the different chemical components of grains and cereal products (Fulcher and Wong 1980, Autio and Salmenkallio-Marttila 2003).

The grain consists of separate tissues with special functions. The embryo will generate the new plant, the starchy endosperm stores the nutrients needed for the growth of the seedling, the aleurone layer is needed for the mobilisation of the stored nutrients and the seed and fruit coat and husks protect the seed. Although the morphology of cereal grains share many similar features, differences exist especially in chemical composition and distribution of components. The lipid content of oat is high (5-9\%) and the grain is also rich in protein, but the starch content is lower than in wheat, rye and barley (39-55\%). The main cell wall polysaccharide in oat is mixed-linkage $(1 \rightarrow 3)(1 \rightarrow 4)$ - $\beta$-D-glucan $(\beta$-glucan) (Fulcher and Miller 1993). $\beta$-Glucan is located in the cell walls, especially in the outer parts of the starchy endosperm. In cultivars with high $\beta$-glucan content the polymer is more even- ly distributed throughout the starchy endosperm, whereas in low $\beta$-glucan cultivars the polymer is concentrated in the subaleurone layer (Fulcher and Miller 1993, Miller and Fulcher 1994). The starch granules of oat are smaller than the granules of e.g. wheat, barley or rye. Oat starch occurs as aggregates composed of several individual starch granules similar to rice starch (Hoseney 1986). The size of the aggregates range from 20 to $150 \mu \mathrm{m}$ in diameter, the size of the individual granules is $2-15 \mu \mathrm{m}$ across (Hoover and Vasanthan 1992, Sowa and White 1992). Cultivar and crop year have been shown to influence relationships of physical, chemical and sensory properties of native and processed oat grains (Lapveteläinen et al. 2001).

A controlled germination and drying process, malting, can be used to modify the texture and flavour of grain (Heiniö et al. 2001, Wilhelmson et al. 2001). During germination endogenous enzymes hydrolyse the different storage compounds of the grain. Malting induces changes in the microstructure of cell walls, proteins and starch granules. Germination changes the flavour profile of the grain (Beal and Mottram 1993). Flavour is also highly influenced by the heat treatment following the germination (Molteberg et al. 1996, Heiniö et al. 2001). Malting also causes $\beta$-glucan degradation. Careful optimisation of the process is needed to preserve the functionality of $\beta$-glucan in malting.

Extrusion cooking, which usually involves high temperature and shear, can be used for the production of fiber-rich products, e.g. snacks and breakfast cereals (Onwulata et al. 2000). Extrusion causes starch gelatinization and mechanically damages the cell wall. To make a puffed whole-grain oat cereal using the extrusion process is difficult because of the high concentration of lipids and soluble $\beta$-glucan of the oat grain. Through blending with corn flour an extruded ready-to-eat cereal product could be made from oat flour (Liu et al. 2000).

The digestibility of starches in cereal products is very much dependent on the intactness of tissue structures, degree of swelling of starch granules and the amount of retrograded amylose 


\section{Salmenkallio-Marttila, M. et al. Relating microstructure and texture of processed oat}

outside the starch granules. Modification of these structural features using processing options can be used to tailor products with desired properties. Understanding of the structure and chemistry of grain components is the basis for developing industrial processes for cereals. In process and product development knowledge of the interactions between the ingredients and effects of processing conditions is required. The knowledge of structure-function relationships of the raw materials and products is valuable in order to achieve the quality required of successful products.

This study is a part of a larger project aiming to produce new, healthy, and tasty food ingredients from oat. In our earlier work we studied the effect of the germination process on the chemical and microbiological quality of oat (Wilhelmson et al. 2001) and specified factors affecting the sensory profile of germinated oat (Heiniö et al. 2001 and 2002). The aim of the present work was to assess the effects of processing on texture and microstructure of grains.

\section{Material and methods}

\section{Oat samples}

The hulled oat cultivar Veli and hull-less cultivar Lisbeth were used in native and processed forms. Six different samples of both cultivars were analysed: native, autoclaved, germinated, germinated-autoclaved, native-extruded and germinated-extruded. The grains were germinated at $+15^{\circ} \mathrm{C}$ for 3 days (steeping and germination, Wilhelmson et al. 2001). The germinated grains were dried to $5 \%$ moisture content using hot air to raise the temperature gradually from 65 to $93^{\circ} \mathrm{C}$ over $19 \mathrm{hr}$ (Heiniö et al. 2001). Moisture contents of the native samples were $11.8 \%$ (cv. Veli) and $11.4 \%$ (cv. Lisbeth).

\section{Extrusion cooking}

Native and germinated grains were milled (Wiley mill, 2-mm sieve) and extruded in Clextral BC-45 co-rotating twin-screw extruder using 4 $\mathrm{mm}$ die with a screw assembly including a 50 $\mathrm{mm}$ reverse-flighted screw element. Moisture content of the feed was $20-22 \%$, temperature $150^{\circ} \mathrm{C}$ and screw speed $150 \mathrm{rpm}$. Cross-section of the extrudate was $4 \mathrm{~mm}$ and final moisture content $5 \%$.

\section{Autoclaving}

Native and germinated samples of grains were autoclaved $\left(120^{\circ} \mathrm{C}, 30 \mathrm{~min}\right)$. After cooking the grains were dried to $20 \%$ moisture content in microwave oven for $3 \times 2 \mathrm{~min}$ and $1 \times 1 \mathrm{~min}$. The final drying to $5 \%$ moisture content was performed in temperature cabinet at $105^{\circ} \mathrm{C}$ for $1 \mathrm{~h}$.

\section{Light microscopy}

Transverse sections were taken from the middle of the grain, fixed in $1 \%$ glutaraldehyde in 0.1 M phosphate buffer ( $\mathrm{pH}$ 7.0) dehydrated with ethanol, embedded in Historesin (Leica, Heidelberg) and sectioned with a rotary microtome. For the fluorescence microscopy the sections $(4 \mu \mathrm{m})$ were stained with $0.1 \%$ (w/v) acid fuchsin (Gurr, BDH Ltd, Poole, England) and $0.01 \%(w / v) ~ C a l-$ cofluor white (Fluorescent brightener 28, Aldrich, Germany). For bright field microscopy the sections were stained with $0.1 \%(\mathrm{w} / \mathrm{v})$ light green (Gurr, BDH Ltd, Poole, England) and Lugol's iodine $\left(\mathrm{I}_{2} 0.33 \%\right.$, w/v and KI $0.67 \%$, $\mathrm{w} / \mathrm{v}$, diluted 1:10). The samples were examined with an Olympus BX-50 microscope (epifluorescence, excitation 330-385 $\mathrm{nm}$, emission $>420 \mathrm{~nm}$ ). Micrographs were obtained using a SensiCam CCD camera (PCO, Kelheim, Germany) and the AnalySIS 3.0 image analysis program (Soft Imaging System, Münster, Germany). 


\section{Instrumental analysis}

Hardness of the grains was measured by cutting a grain transversally from the dorsal side in halves with a knife blade (knife blade HDP/BSK, load cell 5kg, TA-HDi Texture Analyser, Stable Micro Systems, Godalming, UK). The maximum force and cutting energy (area of the force curve) needed to cut the grain were used to describe hardness of the grain. The knife speed was $1 \mathrm{~mm}$ $\mathrm{s}^{-1}$. Results are given as the average value of 20 grains.

Milling energy of the samples was determined by grinding $5 \mathrm{~g}$ samples with the standard method for malt (Comparamill, Rogarth Enterprises Ltd., Scotland; Allison et al. 1976, 1979, Cowe et al. 1989). Two replicate samples of each product were measured.

\section{Sensory analysis}

The sensory quality of the oat samples was evaluated by a trained internal panel $(\mathrm{n}=8-15)$ in two replicate sessions using descriptive sensory profile analysis as described earlier (Heiniö et al. 2002). The vocabulary of the sensory attributes was developed in a round-table session by describing differences among 17 widely varying oat products by a six-member expert panel specialised in cereal products. The expert panel was part of the internal panel trained in sensory analysis of cereal products. The panel became familiar with the sensory descriptors and the attribute intensities of native and processed oat in a few training sessions with real samples, and by using verbal definitions describing the ends of intensity scales of the attributes. The samples were presented to the panelists in random order out of plastic containers covered by lids. The closed containers were prepared 1-2 $\mathrm{hr}$ before evaluation. Sample size was 10-20 grams. Water was provided for cleansing the palate between the samples. Attribute intensities were rated on continuous unstructured graphical intensity scales. The scales were verbally anchored at each end; the left side of the scale corresponded to the lowest intensity (value 0 ) and the right side to the highest intensity (value 10) of the attribute. Scores were recorded and collected using computerised data systems (Panel 5 v.4.00, Legolas Oy, Finland, or Compusense Five v.4.0, Guelph, ON, Canada).

\section{Statistical analysis}

The significance of each descriptive attribute in discriminating between the samples was investigated using analysis of variance (ANOVA) and Tukey's honestly significant difference (HSD) test (significance of differences at $\mathrm{P}<0.05$ ) by the general linear model (GLM) procedure using statistical software (v. 8.0.2, SPSS). Partial least squares regression (PLS, Unscrambler v. 7.5, CAMO ASA) was used to relate the sensory data with the instrumental texture measurements. The sensory data used for the multivariate analysis were means calculated over all panellists.

\section{Results}

\section{Microstructure}

In cv. Veli the cells of the starchy endosperm were smaller than in cv. Lisbeth, and $\beta$-glucan was concentrated in the subaleurone layer (Fig. 1a). The cells appeared to be packed full with starch granules that were tightly surrounded by the protein matrix (Fig. 2a). In cv. Lisbeth there appeared to be a large number of small starch granules that were less tightly surrounded with protein (Fig. 2b). In cv. Lisbeth grains $\beta$-glucan was more evenly distributed in the starchy endosperm than in cv. Veli (Fig. 1b). In the autoclaved samples starch was gelatinized and cell walls were swollen. In cv. Lisbeth grains $\beta$-glucan appeared to be more hydrolysed than in cv. Veli, as the blue fluorescence of Calcofluor had clearly diminished in comparison to the native grains. In cv. Lisbeth the starch appeared 


\section{Salmenkallio-Marttila, M. et al. Relating microstructure and texture of processed oat}

more swollen and filled the cells (Fig. 2d), whereas in cv. Veli there appeared to be more protein around the starch (Fig. 2c).

The germination time used for the samples was short (steeping and germination together 3 days) to retain the valuable cell wall component $\beta$-glucan as intact as possible. The starchy endosperm of the germinated grains appeared more fragile than the structure of the native grains and was partly crumbled (Fig. 1c and d). The largest changes due to germination were apparent in the crushed cell layer beneath the scutellum, where $\beta$-glucan had been degraded in both cultivars. In cv. Lisbeth (Fig. 1d) $\beta$-glucan had been degraded in a wider area in the dorsal side of the grain and subaleurone layer than in cv. Veli (Fig. 1c). No changes in starch were observed but the structure of the protein network was more dense and surrounded the starch granules more tightly than in the native grains (Fig. 2f). After autoclaving the structure of the germinated grains was even more fragmented but the pattern of disintegration was different (Fig. 1e). In the germinated grains the structure was crumbling to starchy flour, especially in the areas were cell walls had disintegrated, whereas the autoclaved grains were splitting into large particles between the cells.

Native and germinated grains were milled before extrusion cooking, which determines the particle size seen in the images. In all samples the starch granules appeared molten and protein formed large dense clusters (Fig. 2e). Irregularly shaped pores dominated the structure of the cereal crisps. Cell walls were swollen and contorted but the samples contained also large intact-looking grain particles consisting of aleurone and subaleurone layers (Fig. 1f). After Calcofluor staining the native extruded samples contained only a small amount of blue fluorescence indicating hydrolysis of $\beta$-glucan. In the germinated extruded samples $\beta$-glucan was fluorescing strongly.

\section{Instrumental texture}

The milling energy test has been developed for the evaluation of hardness of barley and malt samples (Allison et al. 1976, 1979, Cowe et al. 1989). High milling energy values indicate hard and steely endosperm, low milling energy values indicate a soft and mealy structure. The measurement is fast and easy to perform. It works best when differences between samples of the same cultivar are compared. Native and autoclaved samples had the highest milling energies (Fig. 3a). Milling energies of the germinated samples were smaller than those of the native grains. Extruded cv. Lisbeth-samples had the lowest milling energies.

Instrumental hardness was measured by cutting single grains in two and measuring the force and energy needed (Fig. 3b, c). The maximum force was taken to describe the hardness of the grains: the more force is needed for cutting, the harder the grain. The area under the measured force curve appeared to depict brittle hardness: a brittle and crisp texture is cut with less force. The extruded samples had very different texture than the other samples, partly because the grains were ground before extrusion cooking, partly because the open cell structure the material formed during treatment. The autoclaved grains were hardest, when hardness was measured as maximum force needed for cutting (Fig. 3b). From the extrusion cooked samples cv. Veli produced harder structure than cv. Lisbeth. The native grains were tougher than the processed grain, when texture was measured as force area (Fig. $3 c)$.

\section{Sensory evaluation}

Six odour, ten flavour and five sensory texture attributes were evaluated from the samples (Tables 1-3). Roasted odour and flavour were especially typical for the germinated-dried grains $(\mathrm{P}<0.05)$ (Table 1). Also the intensity of odour and flavour, sweetness and surprisingly moistness of odour were more pronounced in the ger- 


\section{AGRICULTURAL AND FOOD SCIENCE}

Vol. 13 (2004): 124-137.
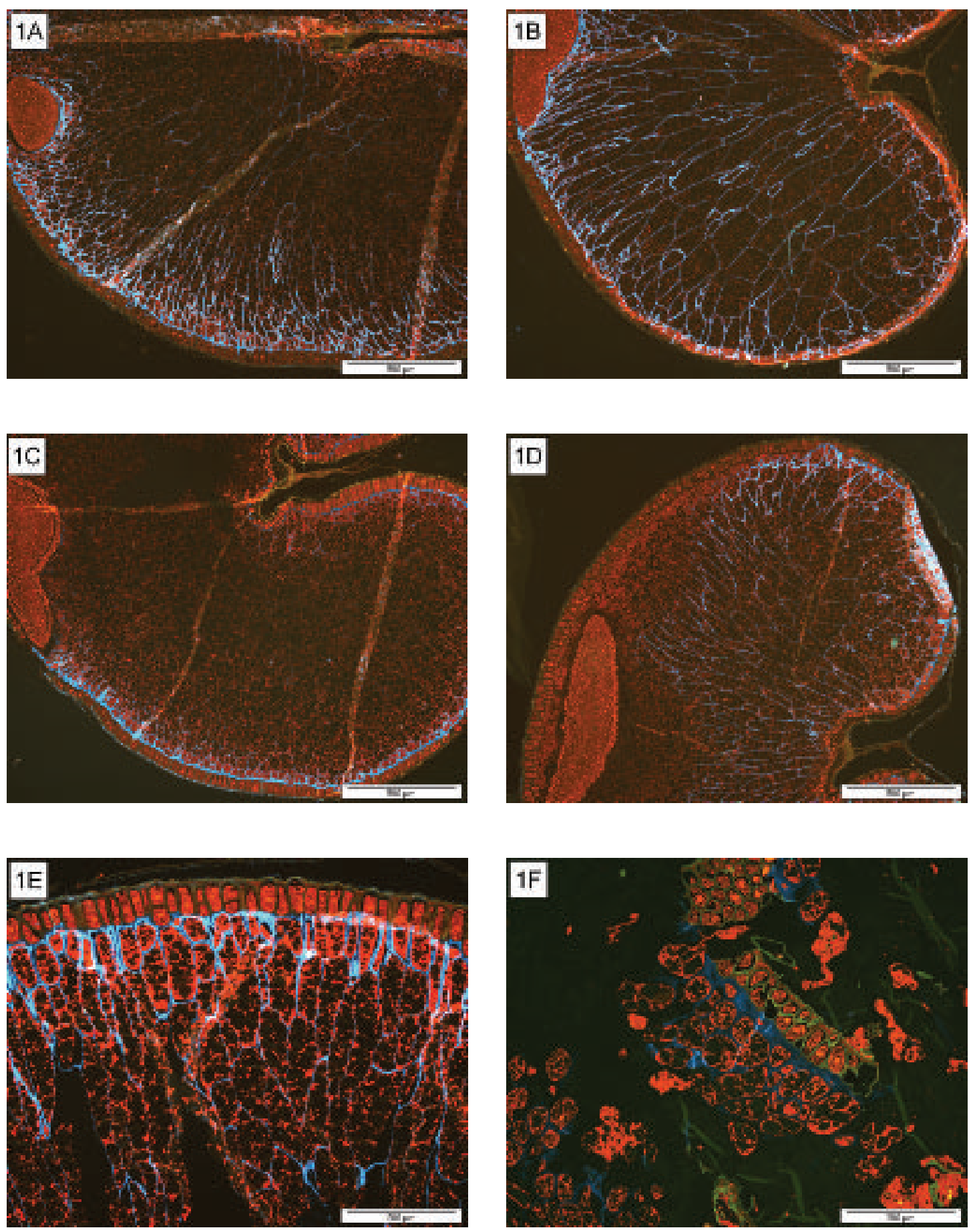

Fig. 1. Effect of processing on microstructure of oat. The sections were stained with acid fuchsin and calcofluor. Primary cell walls containing $\beta$-glucan appear blue, protein red and starch black. a) native cv. Veli, b) native cv. Lisbeth, c) germinated cv. Veli, d) germinated cv. Lisbeth, e) germinated-autoclaved cv. Lisbeth, f) native-extruded cv. Lisbeth. 
Salmenkallio-Marttila, M. et al. Relating microstructure and texture of processed oat
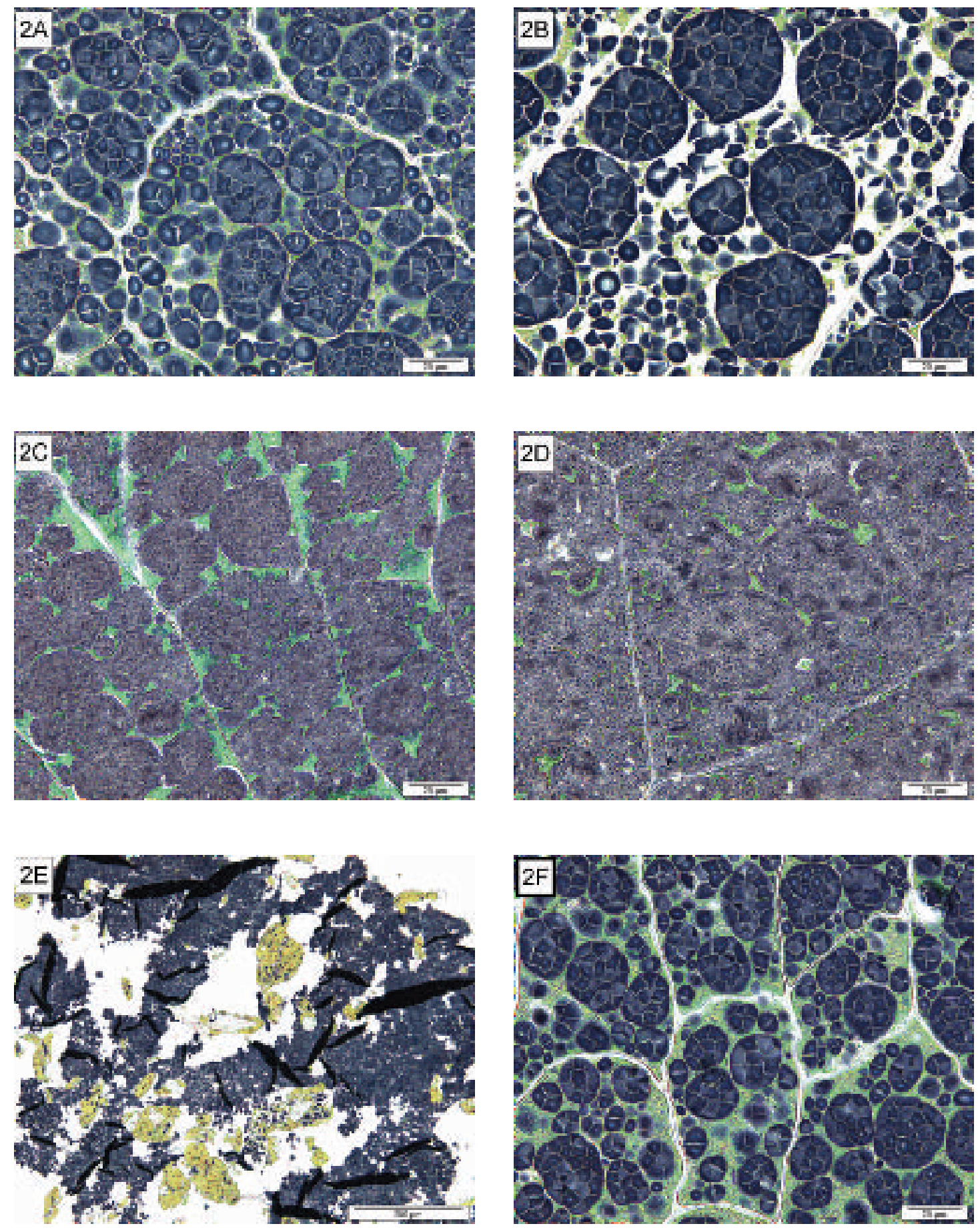

Fig. 2. Effect of processing on microstructure of oat. The sections were stained with light green and iodine. Starch granules appear violet and protein green. a) native cv. Veli, b) native cv. Lisbeth, c) autoclaved cv. Veli, d) autoclaved cv. Lisbeth, e) germinated-extruded cv. Veli, f) germinated cv. Lisbeth. 
Vol. 13 (2004): 124-137.

a)

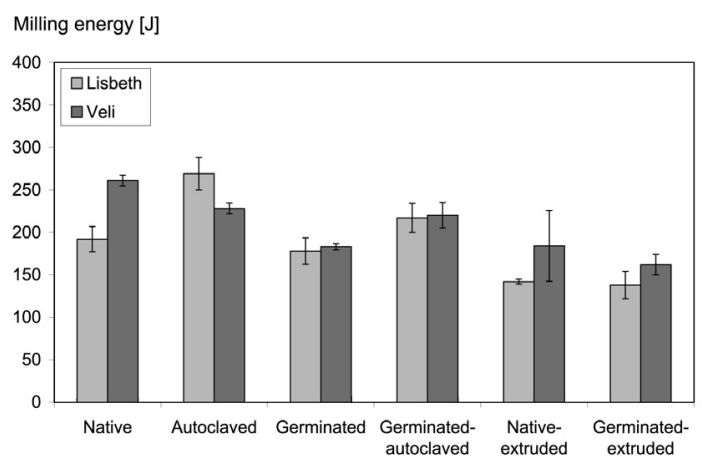

c)

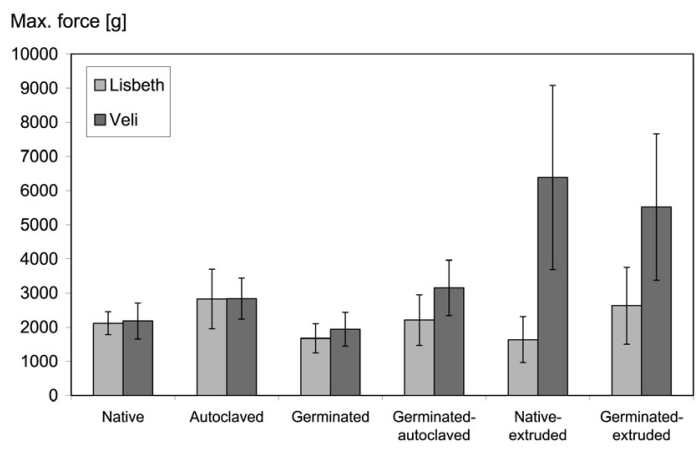

minated-dried grains. The flavour of germinated-dried cv. Lisbeth was evaluated more germlike than the others. The texture of germinateddried cv. Veli was evaluated as less tough and more crisp and brittle than the texture of the other samples $(\mathrm{P}<0.05)$.

Autoclaving affected the sensory properties of the two oat cultivars Veli and Lisbeth differently (Table 2). There was no statistically significant difference $(\mathrm{P}<0.05)$ in the sensory texture attributes of the two oat varieties after autoclaving. Roasted odour and flavour was especially typical for germinated-autoclaved grains $(\mathrm{P}<$ 0.05 ) (Table 2). Germinated-autoclaved cv. Lisbeth had the least earthy odour, native-autoclaved cv. Veli the most. However, the flavour of the germinated-autoclaved cv. Lisbeth was evaluated as the most musty and the germinated-autoclaved cv. Veli the least musty. The germinatedautoclaved cv. Veli was also less bitter and sweeter than the other samples evaluated. b)

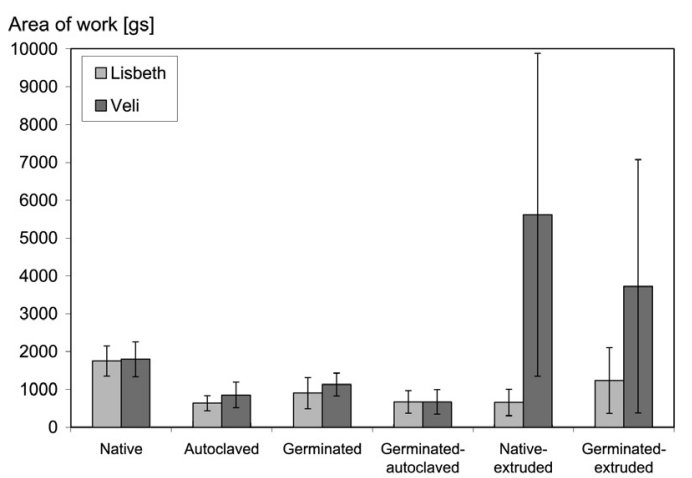

Fig. 3. Effect of processing on instrumental texture of oat cv. Veli and cv. Lisbeth. a) milling energy, b) hardness, c) cutting energy.

Roasted odour and flavour were typical for the germinated-dried-extruded oats $(\mathrm{P}<0.05)$ (Table 3). Especially the germinated-dried-extruded cv. Veli had a strong roasted odour and flavour. Native-extruded cv. Lisbeth had weaker odour and flavour and was evaluated as less sweet than the other oat samples. It also had a weak aftertaste. There was a statistically significant difference between the extruded oat samples in the texture attributes hard and crisp $(\mathrm{P}<$ 0.05). Native-extruded cv. Lisbeth was softer than either of the extruded cv. Veli samples.

There was no difference between the samples in some of the attributes tested (e.g. earthy odour, rancid flavour), whereas some of the attributes were largely affected by the processes used. The most pronounced differences between the samples were obtained in roasted odour and flavour: germinated-extruded cv. Veli was evaluated as most roasted and germinated -dried cv. Veli was a good second, whereas the native 
Salmenkallio-Marttila, M. et al. Relating microstructure and texture of processed oat

Table 1. Effect of germination and drying process on sensory quality of oat cultivars Lisbeth and Veli. Mean descriptive sensory analysis ratings on a scale $0-10$. Native samples $n=15$; Lisbeth germinateddried $\mathrm{n}=8$, 9; Veli germinated-dried $\mathrm{n}=10,10$.

\begin{tabular}{|c|c|c|c|c|}
\hline \multirow[t]{2}{*}{ Sensory attribute } & \multicolumn{2}{|c|}{ Lisbeth } & \multicolumn{2}{|r|}{ Veli } \\
\hline & Native & Germinated-dried & Native & Germinated-dried \\
\hline \multicolumn{5}{|l|}{ Odour } \\
\hline Cereal & 5.5 & 5.0 & 6.0 & 5.5 \\
\hline Roasted & $0.7^{\mathrm{a}}$ & $4.6^{\mathrm{b}}$ & $1.1^{\mathrm{a}}$ & $5.5^{\mathrm{b}}$ \\
\hline Moist & $0.8^{\mathrm{a}}$ & $2.8^{\mathrm{b}}$ & $0.6^{\mathrm{a}}$ & $1.2^{\mathrm{ab}}$ \\
\hline Musty & 1.9 & 2.2 & 2.3 & 1.9 \\
\hline Earthy & 0.5 & 2.2 & 1.0 & 1.4 \\
\hline Intense & $1.8^{\mathrm{a}}$ & $4.2^{\mathrm{bc}}$ & $2.9^{\mathrm{ab}}$ & $4.8^{\mathrm{c}}$ \\
\hline \multicolumn{5}{|l|}{ Flavour } \\
\hline Cereal & 7.5 & 5.8 & 6.9 & 6.3 \\
\hline Roasted & $1.2^{\mathrm{a}}$ & $5.9^{\mathrm{b}}$ & $1.3^{\mathrm{a}}$ & $6.1^{\mathrm{b}}$ \\
\hline Nutty & 3.8 & 4.4 & 3.3 & 5.2 \\
\hline Sweet & $1.5^{\mathrm{a}}$ & $3.7^{\mathrm{b}}$ & $2.1^{\mathrm{a}}$ & $4.2^{\mathrm{b}}$ \\
\hline Bitter & 1.9 & 3.7 & 2.3 & 2.8 \\
\hline Germ-like & $0.5^{\mathrm{a}}$ & $3.2^{\mathrm{b}}$ & $0.4^{\mathrm{a}}$ & $1.2^{\mathrm{a}}$ \\
\hline Musty & 1.8 & 3.2 & 1.9 & 2.0 \\
\hline Rancid & 1.4 & 1.5 & 1.0 & 0.7 \\
\hline Intense & $3.6^{\mathrm{a}}$ & $5.7^{\mathrm{b}}$ & $3.4^{\mathrm{a}}$ & $5.8^{\mathrm{b}}$ \\
\hline Aftertaste & 3.4 & 4.2 & 2.8 & 4.4 \\
\hline \multicolumn{5}{|l|}{ Texture } \\
\hline Hard & 6.9 & 6.3 & 7.2 & 6.5 \\
\hline Tough & $5.8^{\mathrm{b}}$ & $4.0^{\mathrm{ab}}$ & $5.7^{\mathrm{b}}$ & $2.2^{\mathrm{a}}$ \\
\hline Moist & 1.7 & 1.9 & 1.7 & 0.8 \\
\hline Crisp & $2.5^{\mathrm{a}}$ & $5.9^{\mathrm{b}}$ & $3.1^{\mathrm{a}}$ & $7.3^{\mathrm{c}}$ \\
\hline Brittle & $2.4^{\mathrm{a}}$ & $3.9^{\mathrm{ab}}$ & $2.2^{\mathrm{a}}$ & $5.0^{\mathrm{b}}$ \\
\hline
\end{tabular}

${ }^{\mathrm{a}-\mathrm{c}}$ Values of each sensory attribute followed by the same letter are not significantly different $(\mathrm{P}<0.05)$.

grains had no roasted odour or flavour. Germinated-dried cv. Lisbeth had moister odour and more bitter and germ-like flavour than the other processed or native oat samples. Native-extruded cv. Lisbeth and cv. Veli as well as germinated-extruded cv. Lisbeth had mustier odour. Native cv. Lisbeth had weakest odour. Germinated-dried cv. Lisbeth and cv. Veli were evaluated as more nutty in flavour than the other samples. The highest flavour intensities were in the germinated-extruded cv. Veli and cv. Lisbeth.

There were differences in all the analysed perceived texture attributes (Tables 1-3). Nativeautoclaved cv. Lisbeth had the hardest texture and native-extruded cv. Lisbeth the least hard. Native cv. Lisbeth and cv. Veli were more tough and moist and less crisp and brittle than the other samples. Also the germinated-dried cv. Lisbeth was evaluated as tough and moist. The differences in texture attributes appeared to be more pronounced between the native and processed oats, even though the germinated-dried cv. Lisbeth differed from the other processed samples to some extent.

\section{Relating instrumental and sensory texture}

A correlation matrix was used to study correlations between the instrumental texture properties (cutting energy, hardness and milling ener- 
Vol. 13 (2004): 124-137.

Table 2. Effect of autoclaving on sensory quality of native and germinated oat cultivars Lisbeth and Veli. Mean descriptive sensory analysis ratings on a scale $0-10 . n=10$, two replicates

\begin{tabular}{|c|c|c|c|c|}
\hline \multirow[t]{2}{*}{ Sensory attribute } & \multicolumn{2}{|c|}{ Lisbeth } & \multicolumn{2}{|c|}{ Veli } \\
\hline & $\begin{array}{c}\text { Native- } \\
\text { autoclaved }\end{array}$ & $\begin{array}{c}\text { Germinated- } \\
\text { autoclaved }\end{array}$ & $\begin{array}{c}\text { Native- } \\
\text { autoclaved }\end{array}$ & $\begin{array}{l}\text { Germinated- } \\
\text { autoclaved }\end{array}$ \\
\hline \multicolumn{5}{|l|}{ Odour } \\
\hline Cereal & 4.0 & 3.3 & 3.6 & 3.5 \\
\hline Roasted & $2.7^{\mathrm{a}}$ & $5.1^{\mathrm{b}}$ & $2.3^{\mathrm{a}}$ & $3.4^{\mathrm{ab}}$ \\
\hline Moist & 1.3 & 1.0 & 1.2 & 1.1 \\
\hline Musty & 1.3 & 1.1 & 1.6 & 1.0 \\
\hline Earthy & $1.0^{\mathrm{ab}}$ & $0.3^{\mathrm{a}}$ & $1.0^{\mathrm{b}}$ & $0.5^{\mathrm{ab}}$ \\
\hline Intense & 3.3 & 4.2 & 3.1 & 3.4 \\
\hline \multicolumn{5}{|l|}{ Flavour } \\
\hline Cereal & 4.6 & 5.2 & 4.4 & 4.7 \\
\hline Roasted & $2.9^{\mathrm{ab}}$ & $4.9^{\mathrm{b}}$ & $2.2^{\mathrm{a}}$ & $4.0^{\mathrm{ab}}$ \\
\hline Nutty & 2.3 & 2.2 & 2.2 & 2.7 \\
\hline Sweet & $1.6^{\mathrm{a}}$ & $2.9^{\mathrm{ab}}$ & $2.2^{\mathrm{ab}}$ & $3.6^{\mathrm{b}}$ \\
\hline Bitter & $1.0^{\mathrm{b}}$ & $0.8^{\mathrm{b}}$ & $0.5^{\mathrm{ab}}$ & $0.2^{\mathrm{a}}$ \\
\hline Germ-like & 0.7 & 1.0 & 0.7 & 0.7 \\
\hline Musty & $1.7^{\mathrm{ab}}$ & $2.1^{\mathrm{b}}$ & $1.2^{\mathrm{ab}}$ & $0.7^{\mathrm{a}}$ \\
\hline Rancid & 0.3 & 0.3 & 0.3 & 0.2 \\
\hline Intense & $4.2^{\mathrm{a}}$ & $5.7^{\mathrm{b}}$ & $3.7^{\mathrm{a}}$ & $4.9^{\mathrm{ab}}$ \\
\hline Aftertaste & 2.7 & 4.0 & 2.2 & 2.8 \\
\hline \multicolumn{5}{|l|}{ Texture } \\
\hline Hard & 8.7 & 8.3 & 8.3 & 8.3 \\
\hline Tough & 1.9 & 1.4 & 1.8 & 1.3 \\
\hline Moist & 0.5 & 0.4 & 0.6 & 0.4 \\
\hline Crisp & 6.1 & 7.1 & 6.9 & 7.4 \\
\hline Brittle & 4.0 & 4.8 & 4.1 & 5.0 \\
\hline
\end{tabular}

${ }^{a-b}$ Values of each sensory attribute followed by the same letter are not significantly different $(\mathrm{P}<0.05)$.

gy) and the sensory texture attributes (hardness, toughness, moistness, crispness and brittleness). Cutting energy correlated with instrumental hardness and milling energy correlated with sensory hardness $(r=0.70)$ (Table 4$)$. Sensory hardness correlated also with sensory moistness, crispness and brittleness, and moistness with crispness and brittleness.

The effects of different processing methods on the instrumental texture and sensory profile of the two oat varieties were evaluated with multivariate statistical PLS regression (Fig. 4a, b). The first factor of the PLS model explained 98\% of the variation of the instrumental results and $19 \%$ of the variation of the sensory data within the oat samples, and the second factor explained
$2 \%$ and $22 \%$, respectively. The effect of the different processes was clear: irrespective of the oat variety, the native, germinated, autoclaved and germinated-extruded samples formed their own groups (Fig. 4a). When the texture properties were compared, instrumental and sensory hardness were well related, also milling energy correlated reasonably well with sensory hardness (Fig. 4b). In comparing the figures it can be observed that autoclaving creates more crisp and hard texture, whereas germinated samples are depicted by moist sensory texture and the native grains are depicted by toughness. Germination and extrusion cooking created a strong roasted flavour to the oat grain. 
Salmenkallio-Marttila, M. et al. Relating microstructure and texture of processed oat

Table 3. Effect of extrusion cooking on sensory quality of native and germinated oat cultivars Lisbeth and Veli. Mean descriptive sensory analysis ratings on a scale $0-10 . \mathrm{n}=10$, two replicates.

\begin{tabular}{|c|c|c|c|c|}
\hline \multirow[t]{2}{*}{ Sensory attribute } & \multicolumn{2}{|c|}{ Lisbeth } & \multicolumn{2}{|c|}{ Veli } \\
\hline & $\begin{array}{l}\text { Native- } \\
\text { extruded }\end{array}$ & $\begin{array}{c}\text { Germinated- } \\
\text { extruded }\end{array}$ & $\begin{array}{l}\text { Native- } \\
\text { extruded }\end{array}$ & $\begin{array}{c}\text { Germinated- } \\
\text { extruded }\end{array}$ \\
\hline \multicolumn{5}{|l|}{ Odour } \\
\hline Cereal & 4.2 & 5.2 & 4.9 & 5.0 \\
\hline Roasted & $1.9^{\mathrm{a}}$ & $4.9^{b}$ & $4.6^{\mathrm{b}}$ & $7.0^{\mathrm{c}}$ \\
\hline Moist & 1.0 & 0.9 & 0.9 & 0.8 \\
\hline Musty & 4.3 & 3.9 & 4.1 & 2.7 \\
\hline Earthy & 1.9 & 1.7 & 2.2 & 0.8 \\
\hline Intense & $3.5^{\mathrm{a}}$ & $6.3^{\mathrm{b}}$ & $5.6^{\mathrm{b}}$ & $6.5^{\mathrm{b}}$ \\
\hline \multicolumn{5}{|l|}{ Flavour } \\
\hline Cereal & 5.3 & 6.1 & 6.2 & 6.8 \\
\hline Roasted & $2.3^{\mathrm{a}}$ & $5.1^{\mathrm{b}}$ & $4.5^{\mathrm{b}}$ & $7.9^{c}$ \\
\hline Nutty & 2.3 & 4.2 & 2.7 & 3.8 \\
\hline Sweet & $1.6^{\mathrm{a}}$ & $3.9^{c}$ & $1.9^{\mathrm{ab}}$ & $3.4^{\mathrm{bc}}$ \\
\hline Bitter & 2.5 & 2.3 & 2.5 & 2.5 \\
\hline Germ-like & 1.0 & 2.0 & 0.9 & 0.7 \\
\hline Musty & 3.8 & 3.6 & 3.4 & 2.8 \\
\hline Rancid & 1.0 & 0.5 & 0.7 & 0.5 \\
\hline Intense & $3.0^{\mathrm{a}}$ & $6.1^{\mathrm{bc}}$ & $5.1^{\mathrm{b}}$ & $7.0^{\mathrm{c}}$ \\
\hline Aftertaste & $2.0^{\mathrm{a}}$ & $4.7^{\mathrm{b}}$ & $4.0^{\mathrm{b}}$ & $5.4^{\mathrm{b}}$ \\
\hline \multicolumn{5}{|l|}{ Texture } \\
\hline Hard & $5.7^{\mathrm{a}}$ & $7.0^{\mathrm{ab}}$ & $7.8^{\mathrm{b}}$ & $7.2^{\mathrm{b}}$ \\
\hline Tough & 1.4 & 1.2 & 1.6 & 1.3 \\
\hline Moist & 0.6 & 0.4 & 0.4 & 0.4 \\
\hline Crisp & $6.2^{\mathrm{a}}$ & $7.2^{\mathrm{a}}$ & $6.3^{\mathrm{a}}$ & $7.4^{\mathrm{a}}$ \\
\hline Brittle & 4.9 & 4.3 & 3.9 & 3.9 \\
\hline
\end{tabular}

${ }^{a-b}$ Values of each sensory attribute followed by the same letter are not significantly different $(\mathrm{P}<0.05)$.

Table 4. Pearson's Coefficients of correlation between the scores of instrumental (Cutting energy = CuttEn, hardness $=$ Hardn, milling energy $=$ MillEn) and sensory texture $(\mathrm{T})$ attributes.

\begin{tabular}{|c|c|c|c|c|c|c|c|c|}
\hline & CuttEn & Hardn & MillEn & T-HARD & T-TOUGH & T-MOIST & T-CRISP & T-BRITTLE \\
\hline CuttEn & 1.00 & & & & & & & \\
\hline Hardn & 0.89 & 1.00 & & & & & & \\
\hline MillEn & -0.22 & -0.10 & 1.00 & & & & & \\
\hline T-HARD & 0.03 & 0.35 & 0.70 & 1.00 & & & & \\
\hline T-TOUGH & -0.04 & -0.37 & 0.30 & -0.28 & 1.00 & & & \\
\hline T-MOIST & -0.14 & -0.47 & 0.15 & -0.45 & 0.94 & 1.00 & & \\
\hline T-CRISP & -0.04 & 0.27 & -0.30 & 0.21 & -0.93 & -0.78 & 1.00 & \\
\hline T-BRITTLE & -0.28 & -0.03 & -0.33 & 0.05 & -0.85 & -0.69 & 0.89 & 1.00 \\
\hline
\end{tabular}


Vol. 13 (2004): 124-137.

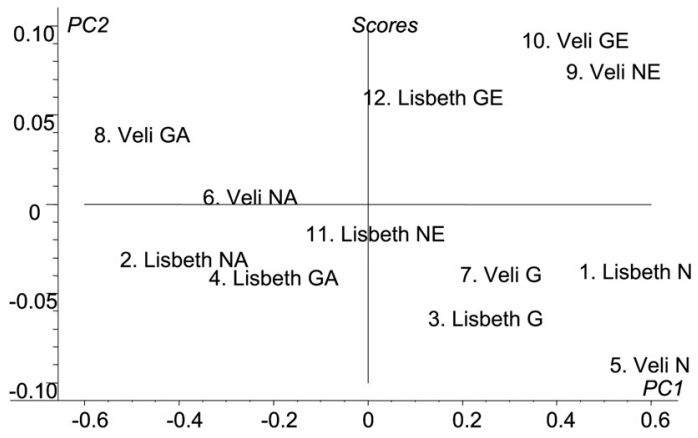

b.

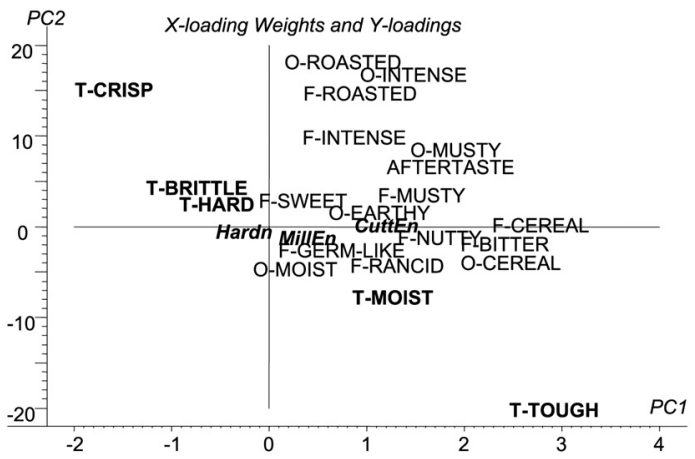

Fig. 4. a) Partial least squares (PLS) score plot of sensory profile attributes and instrumental texture parameters for the processed oat samples. $\mathrm{N}=$ native, $\mathrm{A}=$ autoclaved, $\mathrm{G}=$ germinated, GA = germinated-autoclaved, NE = nativeextruded and GE = germinated-extruded. b) PLS loading plot of sensory profile attributes and instrumental texture parameters for the processed oat samples. $\mathrm{O}=$ odour, $\mathrm{F}=$ flavour, $\mathrm{T}=$ texture.

\section{Discussion}

Oat flavour can be modified and improved by the germination process. Germination alone did not have a significant effect on the desired sensory attributes, but the drying treatment and temperature had a significant effect on the sensory attributes formed (Heiniö et al. 2001). Therefore the effects of different combinations of moisture and heat treatments were studied in this work. The native grain had a mild, cereal-like flavour and a tough texture. The germination process produced a more sweet and intense roasted flavour to the grain and a crisp and brittle texture. Autoclaving had only a slight effect on the flavour of the grains, but the texture of the autoclaved grains was very hard and brittle. Autoclaving of the germinated grains also increased the hardness, crispness and brittleness of the grains. Extrusion cooking of the native grains increased the musty odour and flavour. Extrusion cooking made the texture crisp and brittle but less hard than autoclaving.

The statistical multicomparison method PLS regression has been used for comparing sensory profiles with different processing parameters or chemical variables in processed oat (Dimberg et al. 1996, Liu et al. 2000, Heiniö et al. 2001). In the present study the effects of different processing methods on the instrumental texture and sensory profiles of the two oat varieties were evaluated with PLS regression. The effect of the different processes was clear: irrespective of the variety the native, germinated, autoclaved and germinated-extruded samples formed their own groups. According to the PLS analysis instrumental and sensory hardness were well related. However, the PLS model was not very good as all the instrumental texture parameters were close to zero. In the correlation analysis milling energy was the only instrumental texture attribute that correlated reasonably well with sensory hardness. Of the instrumental methods used in this study the milling energy measurement appeared to be the most useful method for the analysis of the effects of processing on grain structure. The milling energy is fast and easy to measure and the repeatability of the measurement of the different types of samples was also better in the milling energy method than in the other two instrumental methods.

The native grains were depicted by tough sensory structure. One reason for this can be the higher moisture content of the native grains $(12 \%)$ in comparison to the other samples (5\%). Autoclaving produced a brittle and hard sensory texture. The hardness of the native-autoclaved and germinated-autoclaved samples can be con- 


\section{Salmenkallio-Marttila, M. et al. Relating microstructure and texture of processed oat}

nected to gelatinized starch in the microstructure of the autoclaved grains and brittleness to the fracturing of the cell walls.

Some comparisons of the microstructure and instrumentally measured structure of processed oats can be made. The smaller cells of the starchy endosperm of cv. Veli grains can probably explain the higher milling energy of native cv. Veli sample in comparison to the native grains of $\mathrm{cv}$. Lisbeth. The germinated samples in which the cell wall structure had been partially degraded had lower milling energy and lower cutting energy values than the autoclaved and germinated-autoclaved grains; the gelatinization of starch appeared to contribute more than the cell wall structure to the hardness of the groats.

The effects of processing on the grains of the two oat cultivars were similar. In general germination caused cell wall degradation, autoclaving and extrusion cooking caused starch gelatinization. Gelatinization of starch appeared to contribute more to the hardness of oat groats than the cell wall structure. Of sensory texture attributes of processed oat, perceived hardness correlated with hardness measured as milling energy.

Acknowledgements. The skilful technical assistance of Leila Kostamo, Pirkko Nousiainen, Ulla Österlund and EevaKaisa Peltokorpi is gratefully acknowledged. This research was part of the Future Foods research program financed by VTT Biotechnology.

\section{References}

Autio, K. \& Salmenkallio-Marttila, M. 2003. Understanding microstructural changes in biopolymers using light and electron microscopy. In: Kaletunc, G. \& Breslauer, K.J. (eds.). Characterization of cereals and flours. New York, USA: Marcel Dekker Inc. p. 387-408.

Allison, M.J., Cowe, I.A., Borzucki, R., Bruce, F. \& McHale, R. 1979. Milling energy of barley. Journal of the Institute of Brewing 85: 262-264.

Allison, M.J., Cowe, I. \& McHale, R. 1976. A rapid test for the prediction of malting quality of barley. Journal of the Institute of Brewing 82: 166-167.

Beal, A.D. \& Mottram, D.S. 1993. An evaluation of the aroma characteristics of malted barley by free-choice profiling. Journal of the Science of Food and Agriculture 61: 12-22.

Cowe, I.A., Cuthbertson, D.C. \& Swanston, J.S. 1989. The effect of moisture and nitrogen levels on milling energy of barley. Journal of the Institute of Brewing 95: 423-425.

Dimberg, L.H., Molteberg, E.L., Solheim, R. \& Frølich, W. 1996. Variation in oat groats due to variety, storage and heat treatment. I: Phenolic compounds, Journal of Cereal Science 24: 263-272.

Fulcher, R.G. \& Miller, S.S. 1993. Structure of oat bran and distribution of dietary fiber components. In: Wood, P. (ed.). Oat bran. St. Paul, USA: American Association of Cereal Chemists. p. 1-24.

Fulcher, R.G. \& Wong, S.J. 1980. Inside cereals - A fluorescence microchemical view. In: Inglett, G.E. \& Munck, L. (eds.). Cereals for food and beverages. New York, USA: Academic Press. p. 1-26.

Heiniö, R.-L., Lehtinen, P., Oksman-Caldentey, K.-M. \& Poutanen, K. 2002. Differences between sensory profiles and development of rancidity during long-term storage of native and processed oat. Cereal Chemistry 79: 367-375.

Heiniö, R.-L., Oksman-Caldentey, K.-M., Latva-Kala, K., Lehtinen, P. \& Poutanen, K. 2001. Effect of drying treatment conditions on sensory profile of germinated oat. Cereal Chemistry 78: 707-714.

Hoover, R. \& Vasanthan, T. 1992. Studies on isolation and characterization of starch from oat (Avena nuda) grains. Carbohydrate Polymers 19: 285-297.

Hoseney, R.C. 1986. Principles of cereal science and technology. St. Paul, USA: American Association of Cereal Chemists, Inc. 327 p.

Lapveteläinen, A., Alho-Lehto, P., Sinn, L., Laukkanen, T., Lindman, T., Kallio, H., Kaitaranta, J. \& Katajisto, J. 2001. Relationships of selected physical, chemical, and sensory parameters in oat grain, rolled oats, and cooked oatmeal - A three-year study with eight cultivars. Cereal Chemistry 78: 322-329.

Lillford, P.J. 2000. Food, the quality is in the structure. In: Fischer, P. et al. (eds.). Proceedings of the 2nd international symposium on food rheology and structure. Zürich, Switzerland. p. 85-90.

Liu, Y., Hsieh, F., Heymann, H. \& Huff, H.E. 2000. Effect of process conditions on the physical and sensory properties of extruded oat-corn puff. Journal of Food Science 65: 1253-1259.

Miller, S.S. \& Fulcher, R.G. 1994. Distribution of $(1 \rightarrow 3),(1 \rightarrow 4)-\beta$-D-glucan in kernels of oats and barley using microspectrofluorometry. Cereal Chemistry 71: 64-68.

Molteberg, E.L., Solheim, R., Dimberg, L.H. \& Frølich, W. 1996. Variation in oat groats due to variety, storage and heat treatment. II: Sensory quality. Journal of Cereal Science 24: 273-282.

Onwulata, C.I., Konstance, R.P., Strange, E.D., Smith, P.W. \& Holsinger, V.H. 2000. High-fiber snacks extruded from triticale and wheat formulation. Cereal Foods World 45: 470-473.

Poutanen, K. 2000. Effect of processing on the properties of dietary fibre. In: McCleary, D.B.V. \& Prosky, L. (eds.). Advanced dietary fibre technology. London: 
Vol. 13 (2004): 124-137.

Blackwell Science. p. 277-282.

Sowa, S.M. \& White, P.J. 1992. Characterization of starch isolated from oat groats with different amounts of lipid. Cereal Chemistry 69: 521-527.
Wilhelmson, A., Oksman-Caldentey, K.-M., Laitila, A., Suortti, T., Kaukovirta-Norja, A. \& Poutanen, K. 2001. Development of a germination process for producing high b-glucan, whole grain food ingredients from oat. Cereal Chemistry 78: 715-720.

\title{
SELOSTUS
}

\section{Prosessoidun kauran mikroskooppinen ja aistittava rakenne}

\author{
Marjatta Salmenkallio-Marttila, Raija-Liisa Heiniö, Olavi Myllymäki, Martina Lille, Karin Autio ja \\ Kaisa Poutanen \\ VTT Biotekniikka
}

Tutkimuksen tavoitteena oli selvittää, miten prosessointi vaikuttaa kauran jyvien aistittaviin ominaisuuksiin ja mikrorakenteeseen. Prosessoidun jyvän mikroskooppista rakennetta, instrumentaalisesti mitattavaa kovuutta ja aistittavaa rakennetta tutkittiin käsittelemättömistä, idätetyistä, autoklavoiduista, idätetyistä ja autoklavoiduista, ekstrudoiduista sekä idätetyistä ja ekstrudoiduista kauranäytteistä. Materiaalina käytettiin kuorellisen Veli-lajikkeen ja paljasjyväisen Lisbeth-lajikkeen kauranäytteitä.

Veli-kauran tärkkelysendospermin solut olivat kooltaan pienempiä kuin Lisbeth-kauran, ja soluissa oli hyvin runsaasti tärkkelystä. Veli-kaurassa $\beta$-glukaani sijaitsi pääasiassa tärkkelysendospermin uloimmissa solukerroksissa. Sen sijaan Lisbeth-kaurassa oli runsaasti $\beta$-glukaania myös tärkkelysendospermin si- säosien soluseinissä. Lisbeth näytti itävän nopeammin kuin Veli, sillä Lisbeth-lajikkeen jyvien rakenne oli idätyksen aikana hajonnut pitemmälle kuin Velin. Muuten lajikkeet käyttäytyivät eri prosesseissa hyvin samalla tavoin.

Instrumentaalisesti määritetyn rakenteen (leikkausenergia, kovuus ja jauhatusenergia) ja aistitun rakenteen (kovuus, sitkeys, kosteus, rapeus ja hauraus) välisiä riippuvuuksia verrattiin tilastollisilla menetelmillä (korrelaatio- ja regressioanalyysi). Leikkausenergia korreloi instrumentaalisesti määritetyn kovuuden kanssa ja jauhatusenergia aistitun kovuuden kanssa. Käytetyistä mittausmenetelmistä jauhatusenergia näytti parhaiten sopivan mittaamaan prosessoinnin vaikutuksia jyvän rakenteeseen. Menetelmä on nopea ja helppo ja sen toistettavuus on hyvä. 